\title{
Subjective Well-Being within Organizations: A Sociological Explanation
}

\author{
Caterina Galluccio \\ Department of Law and Social Science, Università degli Studi di Chieti Pescara, Via dei Vestini, Italy \\ Email: cgalluccio@unich.it, caterinagalluccio@gmail.com
}

How to cite this paper: Caterina, G. (2018). Subjective Well-Being within Organizations: A Sociological Explanation. Sociology Mind, 8, 107-113.

https://doi.org/10.4236/sm.2018.82008

Received: February 17, 2018

Accepted: March 23, 2018

Published: March 26, 2018

Copyright $\odot 2018$ by author and Scientific Research Publishing Inc. This work is licensed under the Creative Commons Attribution International License (CC BY 4.0).

http://creativecommons.org/licenses/by/4.0/

\section{(c) (i) Open Access}

\begin{abstract}
Is subjective well-being within organizations a top-down or a bottom-up process? In other words, who is responsible for it? A number of theories exist and many support the principle of well-being driven by good leadership. This work takes a different tack. It develops a model of well-being where well-being is seen as the final result of a process that involves all the individuals who work in an organization at each level of the hierarchical structure. The paper argues that subjective well-being within organizations cannot be reduced to a psychological question, instead, it is, above all, a sociological, logical and epistemological issue. For this reason, it is suggested that it cannot depend on a single manager or even on a group of them. The argument finds its roots in the theory of methodological individualism; dispersed and tacit knowledge (F. Hayek and M. Polanyi); the fallibility of human nature (K. Popper); bounded rationality (H. Simon); the distribution of power within organizations (M. Crozier).
\end{abstract}

\section{Keywords}

Well-Being, Organizations, Methodological Individualism

\section{Introduction}

The terms "organization", "society", "State", "public administration", "church", "party", "people", "class" and so on belong to the so-called "collective concepts" extensively used in social sciences and which are pivotal to two major methodological paradigms: individualism and collectivism (or holism). The dispute between these two schools of thought concerns issues at three different levels: ontological, methodological and political.

At an ontological level, individualists and collectivists differ about what corresponds to these collective concepts in practice. 
For the former - the individualists (Menger, 1937; Weber, 1958; Popper, 1990; Simmel, 1976; Hayek, 1967; Boudon, 1985)—these collective concepts do not correspond to anything that is autonomous, specific or distinct from individuals, and therefore they should really be interpreted in terms of individuals who act on the basis of their beliefs and whose actions produce intentional and unintentional effects.

For the latter-the collectivists (Comte, 1985; Durkheim, 1963)—these concepts correspond to the "effective realities" that exist "a priori and independently of the individual" and without which the individual would disappear.

At a methodological level, this concerns the procedure used to explain genesis and change in social institutions, such as the State, the monetary system and language, or the method used to study social phenomena, such as the disappearance of a religion, the birth of a political party, the outbreak of a revolution. For the collectivist, for whom collective realities are unrelated to individuals whose existence and actions would be inexplicable without these collective realities, it is important to study the genesis, development and change of these realities through the laws underpinning this process of change. Instead, for the methodological individualist, for whom only individuals exist, explaining any social phenomenon means explaining individual action, attempting to reconstruct the situation in which the agent now finds him/herself in conjectural terms, and making his actions to some extent intelligible.

At an ethical and political level, discussion focuses on the final purpose, whether this is society, the state, the nation and so on, or the individual. For a methodological individualist, the final purpose is always the individual and individual rights cannot be sacrificed in the name of "raison d'Etat" or any other reified collective entity. In other words, at a political level, what we are talking about is the theme of "individual responsibility": if there is an ineluctable law that guides human history and uses human actions to achieve a supreme purpose unknown to man, then it follows that individuals will not be free to build their own future and this lack of freedom also undermines any responsibility for their actions. For the individualist, on the other hand, the agent is always responsible for his or her action.

This paper put forwards the thesis that the fundamental concepts of methodological individualism - "rationality", the "dispersal of knowledge", "unintentional consequences", the differentiation between Cosmos and Taxis-can help to enrich new conceptual categories for the study of organizations that have traditionally been marked by a collectivistic-systemic approach or have been prey to psychological interpretations.

\section{The Utopian Dream of the "Happiness Manager"}

A number of theories exist and many support the principle of well-being driven by "managers of happiness" or "well being professionals", in other words managers and leaders with the presumed capacity to make their employees happy 
just because of their mere benevolence or their empathetic attitude towards their coworkers. According to these theories employees' wellness is connected to inner capabilities of leaders and managers.

This work takes a different tack. It develops a model of well-being where well-being is seen as the final result of a process that involves all the individuals who work in an organization at each level of the hierarchical structure. The paper argues that subjective well-being within organizations cannot be reduced to a psychological question, instead, it is, above all, a sociological, logical and epistemological issue. For this reason, it is suggested that it cannot depend on a single manager or even on a group of them.

Organizations must be seen as the outcome of the actions and interactions of individuals, actions and interactions that generate intentional and unintentional consequences. It should immediately be said that unintentional consequences are inevitable for logical reasons: first, because every action always has infinite consequences; second, because there are infinite possible chance combinations in independent causal chains; third and last, because the creation and absorption of new information in open systems multiplies the possibility of initiatives and therefore interactions (Hayek, 1997).

It is not unusual for people to desire one thing and obtain something completely different, often even the contrary to what they had intended. If the moral of Bernard de Mandeville's "Fable of the Bees" (1988) is true whereby "private vices can give rise to public benefits", it is equally true that "the road to hell is paved with good intentions", namely that the impossibility of eliminating unintentional consequences should put us on guard against the proposals put forward today by "the well-being professionals" and "managers of happiness". Among others, these include pre-packaged formulas for "happy companies", which ignore the fact that well-being is achieved from bottom up and not imposed top down, even when inspired by individuals filled with good intentions.

Moreover, the utopian dream of creating "the happy company" is undermined by the theoretical arguments of Hume's law which argues that ethical norms cannot be derived from facts, in other words that our most profound values do not have a rational foundation. This principle is the foundation for freedom of conscience, from which it follows that no individual has a privileged point of view that enables him to impose his formula for happiness on others.

For a clearer understanding of the errors lying in wait for the "utopian", it is worth remembering the distinction that Popper draws between what he calls utopian engineering and piecemeal engineering (Antiseri, 2002).

Popper invites us to eliminate concrete evil rather than create abstract good. A proposal based on the idea that "pain and happiness" or "suffering and pleasure" must not be regarded as symmetrical; indeed, the attainment of happiness is less urgent that the prevention of suffering or support given to those who suffer, hence his exhortation to aim to "minimize avoidable suffering" rather than “maximize happiness" (James, 1988).

From what has been said up to here, it follows that piecemeal engineering 
should be applied inside organizations, in other words, well-being must be a gradual accomplishment, the result of resolving the individual problems that arise inside organizations themselves.

\section{Organizations and Scientific Theories: Hypotheses for the Solution of Problems}

Like scientific theories, organizations can also be considered as hypotheses to solve problems or groups of problems. When an individual or a group of individuals develops an idea or a project-with a view to solving a problem (meet a requirement, offer a service, and so on) - they must solve a series of other problems that will otherwise hinder the realization of the project. If we try to imagine the route that an idea follows before it is realized, it clearly will be successful at some point, but it will also encounter mistakes, failures, constraints (environmental, economic, social, political, legal, etc.), unexpected consequences and clashes with other ideas. It therefore follows that an organization will be on each occasion the best hypothesis to achieve a pre-defined end in the light of a given context which-as pointed out above-will produce a sequence of problems.

Therefore, as in science, the "driving force" behind organizations is precisely the "problems" that spark off a creative process (Colozza, 1997) in researchers, and also in businessmen, aimed at identifying the most satisfactory solution. So, in the same way that science progresses through conflicting theories (Popper, 1975, 1984), so organizations "clash" in the market through the mechanism of competition which serves to select the best organizations, namely those best placed to achieve a given aim or that best meet customer and user requirements.

Whether or not they are aware of it, both scientists and entrepreneurs follow the same method. Progress in science and in the market is driven forward by intuition and imagination, and competition selects the best theories and companies (Baldini, 2003). Therefore, both in science and business, the keywords are intuition, imagination, and competition.

As was said earlier, problems and the attempt to resolve them represent the primum movens, both in science and in organizational activities. At this point, it may be useful to quote Ludwig von Mises (1959) who stated that "human beings act to remove some felt uneasiness" and "action is an attempt to substitute a more satisfactory state of affairs for a less satisfactory one. We call such a will fully induced alteration an exchange. A less desirable condition is bartered for a more desirable. What gratifies less is abandoned in order to attain something that pleases more".

From the comments made till now, we can argue that an organization-taxis (Hayek, 1994) - whether economic or bureaucratic in nature, is created in response to a lack of satisfaction; the intentions of its creators are based on the wish to succeed, to make progress, and their desire to satisfy a need and therefore to solve a chain of problems.

In conclusion, man acts because he is unsatisfied and, we might add, because he is "fallible" and "ignorant", which leads us to a further series of reflections. 


\section{The Logical and Epistemological Reasons Underlying the Search for Organizational Well-Being: Ignorance and Fallibility}

A climate of well-being inside organizations is necessary not just for psychological reasons. Well-being is not fostered by "friendliness" or "empathy", nor can it be reduced to a question of ethics. Instead, it is, above all, a logical, gnoseological and epistemological issue. In other words, if we understand well-being to mean a state of "healthy collaboration" between all those who belong to an organization, this state cannot be seen as the result of the "mere benevolence" of a group of individuals in their dealings with other individuals, or the outcome of "more sympathetic" management; it should be regarded as a product of the awareness of human limitations. Ignorance and fallibility are both typical of our human condition; ignorance of what we don't know and what we cannot comprehend, and fallibility in cases where we think we know.

On the subject of ignorance-which is another specifically epistemological question-Friedrich von Hayek (1988) asserts that there a very large body of knowledge exists, which cannot be regarded as scientific in the sense of knowledge of general laws: (...) knowledge of particular circumstances of time and place.

This vast body of knowledge of "particular circumstances of time and place" cannot be centralized or possessed by a single person, but so-called "tacit knowledge" (Polanyi, 1979, 1990) is equally elusive. This is a kind of knowledge that is implicit in behavioral rules, but individuals are unaware of it until something happens that prompts them to discover it.

At every level of the organizational hierarchy, each individual has a baggage of "tacit", "ready-to-use" knowledge, which gives him or her a sense of power over other individuals. Crozier and Friedberg introduce a concept of power which is understood as that "margin of freedom", or means of "controlling areas of uncertainty", or in other words, an autonomous space that each of us can create and keep for ourselves (Crozier \& Friedberg, 1978; Crozier, 2000; Friedberg, 1994). In the accepted sense proposed by these authors, power is not understood as "authority" (in a Weberian sense), but instead as "influence". Knowledge, expertise, experience and organizational rules, therefore, represent a means of power for anyone who controls them in the organization-the power to solve problems - and they can be used to exert influence over those who are excluded.

Moreover, organizations themselves represent a means of overcoming individual limits, our "bounded rationality" (March \& Simon, 1966), because different skills are needed by an organization in order to attain its goals and, as was explained earlier, a single individual cannot offer them all. Therefore, each employee helps to realize the business purpose by pooling his or her own knowledge, and by doing so allows everyone to benefit from the widest possible access to third-party knowledge.

Therefore, the quest for well-being inside organizations-in which well-being 
is understood as a healthy collaboration between individuals in order to achieve the purpose for which the organization was founded-should be seen as the result of a recognition of human ignorance and fallibility.

On the other hand, no one in an organization is infallible, and being aware of this is the first step towards success.

An awareness of their own fallibility should never leave either the "strategic top management" or the "operational nucleus" (Mintzberg, 1996) of an organization.

On this note, it is no coincidence that titles are often found in management magazines today along the lines of "humor and management", "managers and jesters", "good human in the company", "irony and change", as well as invitations "not to be serious just for the sake of being serious". Does irony or not taking oneself too seriously perhaps indicate an awareness of our own limits? What is irony if not the capacity to be critical and aware of our own fallibility and ignorance? Therefore, what sort of approach should we adopt in business?

We can answer these questions using Popper's words, namely "the best synonym for rational is critical' (Popper, 1997).

\section{Conclusion}

The conclusions that can be drawn from the arguments set out in this paper appear to point towards the fact that the "well-being professional" or "happiness manager" is not a person with special virtues and a curriculum that gives him the capacity to decide about other people's happiness. Instead, he is someone who is aware of his own limits, someone who neither ignores nor underestimates the role played by others in helping him to achieve his goals. He is someone who will take action to solve the problems that arise from time to time, while not forgetting that every action can have unintentional consequences and, therefore, he has to be ready to change his ideas and accept those proposed by others.

In this sense, the only possible answer to the question "who is the happiness manager or the well-being professional?" is: anyone in an organization who acts in this way.

\section{References}

Antiseri, D. (2002). Karl Popper, Protagonista Secolo XX. Soveria Mannelli: Rubbettino.

Baldini, M. (2003). Popper e Benetton. Epistemologia per gli imprenditori e gli economisti. Roma: Armando Editore.

Boudon, R. (1985). Il posto del disordine. Bologna: Il Mulino.

Colozza, G. A. (1997). L’immaginazione nella scienza. Soveria Mannelli: Rubbettino Editore.

Comte, A. (1985). Discorso sullo spirito positivo. Roma-Bari: Laterza.

Crozier, M. (2000). Il fenomeno burocratico. Milano: ETAS.

Crozier, M., \& Friedberg, E. (1978). Attore sociale e sistema. Milano: Etas Libri.

De Mandeville, B. (1988). La favola delle api. Roma-Bari: Laterza. 
Durkheim, E. (1963). Le regole del metodo sociologico. Milano: Comunità.

Friedberg, E. (1994). Il potere e la regola. Etaslibri: Dinamica dell'azione organizzata.

James, R. (1988). Ritorno alla ragione. Il pensiero di Popper e l'amministrazione pubblica. Milano: Rusconi.

March, J. G., \& Simon, H. A. (1966). Teoria dell'organizzazione. Milano: Comunità.

Menger, C. (1937). Il metodo nella scienza economica. Torino: UTET.

Mintzberg, H. (1996). La progettazione dell'organizzazione aziendale (pp. 50-53). Bologna: Il Mulino.

Polanyi, M. (1979). La conoscenza inespressa. Roma: Armando.

Polanyi, M. (1990). La conoscenza personale. Milano: Rusconi.

Popper, K. (1984). Epistemologia evoluzionistica. In Paradigmi: rivista di critica filosofica, 2, Milano, Franco Angeli.

Popper, K. R. (1975). La teoria del pensiero oggettivo. Roma: Armando.

Popper, K. R. (1990). La scienza e la storia sul filo dei ricordi. Bellinzona: Intervista di Guido Ferrari Jaca Book-Edizioni Casagrande.

Popper, K. R. (1997). La ricerca non ha fine. Autobiografia intellettuale. Roma: Armando. Simmel, G. (1976). Il conflitto della cultura moderna. Roma: Bulzoni.

von Hayek, F. A. (1967). L'abuso della ragione. Firenze: Vallecchi.

von Hayek, F. A. (1988). L’uso della conoscenza nella società. In F. Donzelli (Ed.), Conoscenza, mercato, pianificazione. Bologna: Il Mulino.

von Hayek, F. A. (1994). Legge, legislazione e libertà (p. 51). Milano: Il Saggiatore.

von Hayek, F. A. (1997). Individualismo: quello vero e quello falso. Soveria Mannelli: Rubbettino Editore.

von Mises, L. (1959). L'azione umana. Torino: UTET.

Weber, M. (1958). Alcune categorie della sociologia comprendente (1913). In M. Weber, (Ed.), Il metodo delle scienze storico-sociali. Torino: Einaudi. 